\title{
THE ANTIQUITY OF SOCIAL INSECTS
}

\author{
By J. C. Bequaert and F. M. Carpenter \\ Harvard University, Cambridge, Mass.
}

The geological antiquity of social habits among the insects has been the subject of much speculation. Estimates of the time of origin of social insects show little agreement and range from the Permian to the Eocene. Up to the present time, however, actual remains of insects belonging to social families have not been found in strata older than the Eocene. For this reason the Cretaceous fossil recently described by Dr. R. W. Brown ${ }^{1}$ as Celliforma favosites is of much entomological interest. In Dr. Brown's opinion this specimen represents the comb of a wasp nest and thus constitutes the earliest geological record of the social wasps and of social insects in general. Through the kindness of Dr. Brown, we have been able to examine the fossil itself and to discuss it with our associates. We are convinced from this examination that Dr. Brown's identification of the fossil is a doubtful one, and are of the opinion that it is not the nest of a social wasp. If this fossil were from a Tertiary deposit, it would have relatively little significance; but being from the Cretaceous, it would, if unquestionably identified, greatly extend the range of the social wasps. Because of this, we have decided to publish a discussion of the fossil and of our reasons for the above conclusion. The antiquity of social habits among the insects is a very complicated question, as we shall indicate later, and all suggestions deserve serious consideration; but we believe that evidence bearing on the subject should be critically and carefully examined before definite conclusions are reached.

The piece of rock containing the fossil is an irregular ironstone nodule, the center of which is occupied by the fossil. One half of the specimen (shown on plate 1 of Dr.

1Amer. Journ. Sci., vol. 239, January, 1941, pp. 54-56. 
Brown's paper) shows a series of dome-shaped projections, arranged in rows; these are regarded by Dr. Brown as casts of the cells of the nest. ${ }^{2}$ The counterpart of the fossil is lined by shallow cavities which fit over the ends of the projections. One portion of this counterpart also has projections like those on the other half, so that when the parts of the concretion are placed together, the dome-shaped projections extend inwards from both sides. This extraordinary condition, which is not mentioned by Dr. Brown, seems to require an explanation, if the specimen is regarded as a nest.

The method by which a wasp nest might be preserved so as to resemble the fossil in question is very difficult to imagine. Dr. Brown has concluded that the specimen represents part of a papery nest like that of Polistes, but he was apparently unable to explain to his own satisfaction the process of preservation, for he left "to the reader the pleasure of speculating as to the circumstances and method by which the original comb became this fossil." It seems clear that in order to have a nest so preserved, particles of sand and mud must have filled the cells and become cemented together while the walls retained their shape. Then, since there is no part of the actual nest remaining, its substance must have been replaced by additional sand and mud, as it disintegrated. In this way a cast of the nest or of a portion of it would be formed. This process of preservation, involving two steps, seems to be inevitable, and it is indicated by the lithology of the fossil, for the sand particles forming the casts of the "cells" differ in size and other details from those replacing the "cell" walls. What seems impossible to us is that the paper nest would retain its shape long enough to allow the filling in the cells to become so hard that it would hold its form after the disintegration of the paper walls. If a paper comb of any living genera of social wasps (i.e., Vespinæ, Polybiinæ, Polistinæ, Ropalidiinæ) were buried and filled with sand and mud, the thin soft walls between the cells would, in our opinion, inevitably disappear within a short time, long before the foreign material could harden. We have not, of course, experimented with a nest to determine how long it could hold its shape under such conditions;

2Dr. Brown refers to the fossil as a mould, but we consider the term cast more appropriate. 
but anyone who has attempted to collect wasp nests without damage to them appreciates their fragility. Even when a nest is suspended from a tree or similar structure under natural conditions, it disintegrates in a few months' time after it has been deserted by the wasps. The most striking feature of the fossil in this connection is that the casts of all "cells" are complete in the preserved portion of the "nest". Because of the fragility of paper nests, it seems impossible for such regularity to be attained; if only a few cells were so preserved, in various parts of the fossil, Dr. Brown's determination of the fossil would seem more probable.

Possibly some method of preservation radically different from that mentioned above can be given in explanation of the "nest"; but our geological associates have been unable to suggest one.

Apart from the difficulty of explaining the preservation of a paper nest, there are several aspects of the fossil which are not at all characteristic of a wasp's nest. Since the fossil shows almost no "structure", comparisons between it and nests of living wasps are very hard to make. Dr. Brown was consequently led to his conclusion by "general appearance and analogy". The following differences between the fossil and the nests of Recent social wasps seem to us to be significant: a) The dome-shaped tops of the projections were considered by Dr. Brown to be the casts of bottoms of the cells. Now, although the top or open ends of the cells in a wasp nest show a regular arrangement, the bottoms or lower ends are irregularly arranged, as can easily be seen in sections or when the paper covering over this part of the nest is removed. Consequently, the regular arrangement of the lower ends of the cells in the fossil is not at all suggestive of a wasp nest. ${ }^{3}$ b) The bottoms of the cells of Vespid nests are not dome-shaped, as in the fossil, but are flattened or angular. Also the level of the bottoms of the various cells is irregular, so that casts of them would be variable in height as well as in shape. This is not true of the fossil, however,

3The regularity of the "cells" in the fossil resembles the structure of the nests of some Meliponidæ and bumble-bees more than that of a wasp. There are other objections, however, which eliminate these as a possible interpretation of the fossil. 
for the projections are remarkably uniform in shape and height. c) The cells of Vespid nests tend to radiate from the base of the nest, the individual cells being distinctly wider at their openings than at their bases. In the fossil the "cells" have a constant width for their entire length and there is no indication of a radiating arrangement. d) the walls in the cells of a wasp nest are of paper thickness only; in the fossil the substance between the "cells" is nearly as thick as half the diameter of the "cells".

These discrepancies between the fossil and the structure of known Recent Vespid nests, in addition to the difficulty of accounting for preservation of such a fragile structure, lead us to reject Dr. Brown's conclusions regarding this specimen. We believe the interpretation of Celliforma favosites is altogether too uncertain and problematical for it to be accepted as a Cretaceous wasp nest without more proof than has been offered and in view of the total absence of remains of fossil Vespidae, either social or solitary, from that period.

We might point out that there is some superficial resemblance between Dr. Brown's fossil and certain "fossil nests" which have been recently described from Uruguay by F. Lucas Roselli, ${ }^{4}$ and which are thought to be of Cretaceous age, also. We refer particularly to the fossil named Uruguay auroranormai, which shows a somewhat similar arangement of cells of even diameter from top to bottom, ending in domeshaped bases; the cells are not represented by casts, however, but are hollow, with their own walls preserved. If such structures were filled with sand or mud, they might presumably after hardening become "fossils" similar to that described by Dr. Brown. Some of the Uruguayan nests are claimed by Roselli to be the work of solitary diplopterous wasps, although this seems to us extremely problematical. Without examining these nests and knowing more about the conditions under which they occur, we cannot of course discuss them further; but they look suspiciously like nests built by certain Recent solitary bees. The female of the European Halictus quadricinctus, for example, digs a spacious chamber at the end of a tunnel in the soil, in which she

4Boletin de la Sociedad Amigos de las Ciencias Naturales Kraglievich-Fontana", vol. I, pt. 2, September 1938, pp. 72-102. 
constructs as many as 16 to 20 earthern cells, arranged in a crude comb. ${ }^{5}$

Since incorrect and misleading statements about the geological age of social insects are common in both entomological and paleontological literature,${ }^{6}$ we include here a summary of the evidence bearing on the subject. Parental care of young occurs in many groups of insects (e.g., Embiaria, Hemiptera, Dermaptera, etc.), but truly social habits among Recent insects are confined to members of two orders, Isoptera and Hymenoptera. The earliest Isoptera known are from the Eocene period and the group is well represented in the Baltic amber (Oligocene). Since only the winged or sexual forms have been found fossil, we have no factual knowledge that these Tertiary species were social. However, inasmuch as the social organization of the termites is more highly developed than that of any other insects, it was probably well advanced even in the early Tertiary. This conjecture is supported by the presence in the amber species of the transverse suture along which the wing breaks after the insects have swarmed.

The Hymenoptera as a whole have been found as far back as the Jurassic, from which Siricoid and parasitic types have been described. Social habits have been independently developed many times within the order, as Wheeler has pointed out, but none of the social families have been found in strata below the Eocene. The Formicidæ (ants), which are the most highly social of the Hymenoptera, are represented in several Eocene beds. The presence of workers among these Eocene species is conclusive proof that the ants had a welldeveloped society by that period. This is not surprising, inasmuch as caste differentiation of the Baltic amber ants was as advanced as that of Recent Formicidæ. The social history of the bees (Apoidea) has clearly been very different from that of the ants, for as shown by several Hymenopterists, social habits have been developed on at least three

\footnotetext{
5Bischoff has figured a nest of this solitary bee (Biologie der Hymenopteren, 1927, p. 222, fig. 94.)

6 For example, a recent edition of a standard text of historical geology states that termites and "social ants" occur in Jurassic strata. Actually, neither of these groups has been found in rocks older than the Eocene.
} 
different occasions among these insects. The oldest bees known are from the Baltic amber (Oligocene), and some of these belong to highly social families (Bombidæ, Apidæ). None of the described amber bees, however, can be placed in existing genera of these social families. ${ }^{7}$ Furthermore, since none of the amber bees have been positively identified as workers, there is again no factual evidence that they were social. The social wasps (Vespidæ) have a much weaker social organization than the termites or ants, and as in the case of the bees, social habits have arisen several times among the Vespidæ and even within certain genera of the family (e.g., Stenogaster). The oldest known Vespidæ are from the Eocene, and several Baltic amber species (apparently) belong to existing genera which include social species. This fact by itself does not, however, prove the existence of social habits among the Eocene or Oligocene wasps. Recent Vespidæ have no structural characteristics definitely separating all social species from the solitary ones. Moreover, Recent social Vespidæ scarcely ever show structural differences between the workers and the queen.

As the geological record now stands, therefore, there is definite proof of the existence of social insects only as far back as the Eocene. Furthermore, only one Recent family, the Formicidæ, has a social history extending into that period. The termites have probably had a well developed society for at least as long a time as the ants, though there is no paleontological evidence for that conclusion. The bees and wasps, also, may have had a social development extending beyond the Eocene, but no fossil evidence for that has been found, and the nature of their present social structure is decidedly against that possibility.

7A true Bombus, B. proavitus Cock., has however been found in the Miocene of Washington (state). 

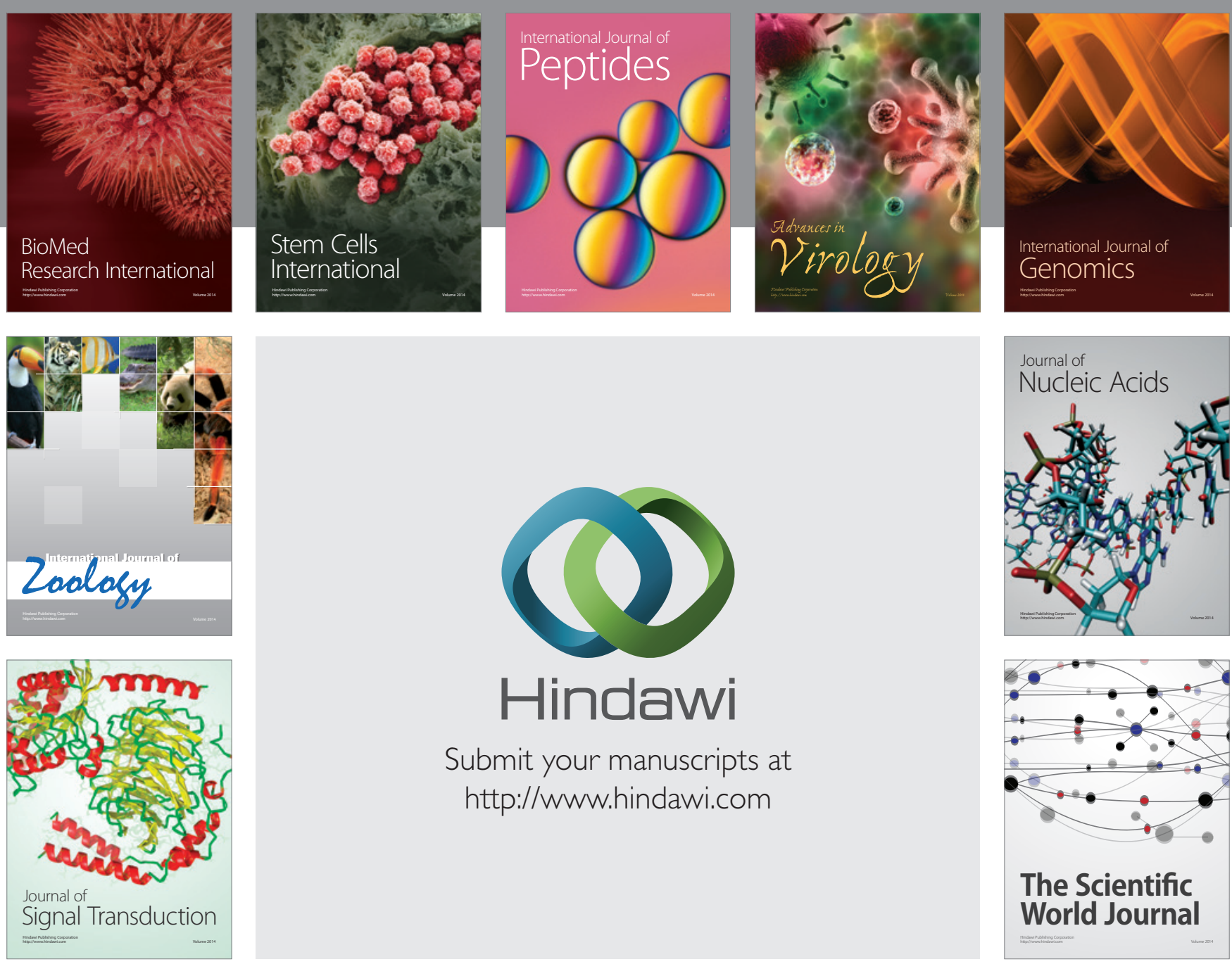

Submit your manuscripts at

http://www.hindawi.com
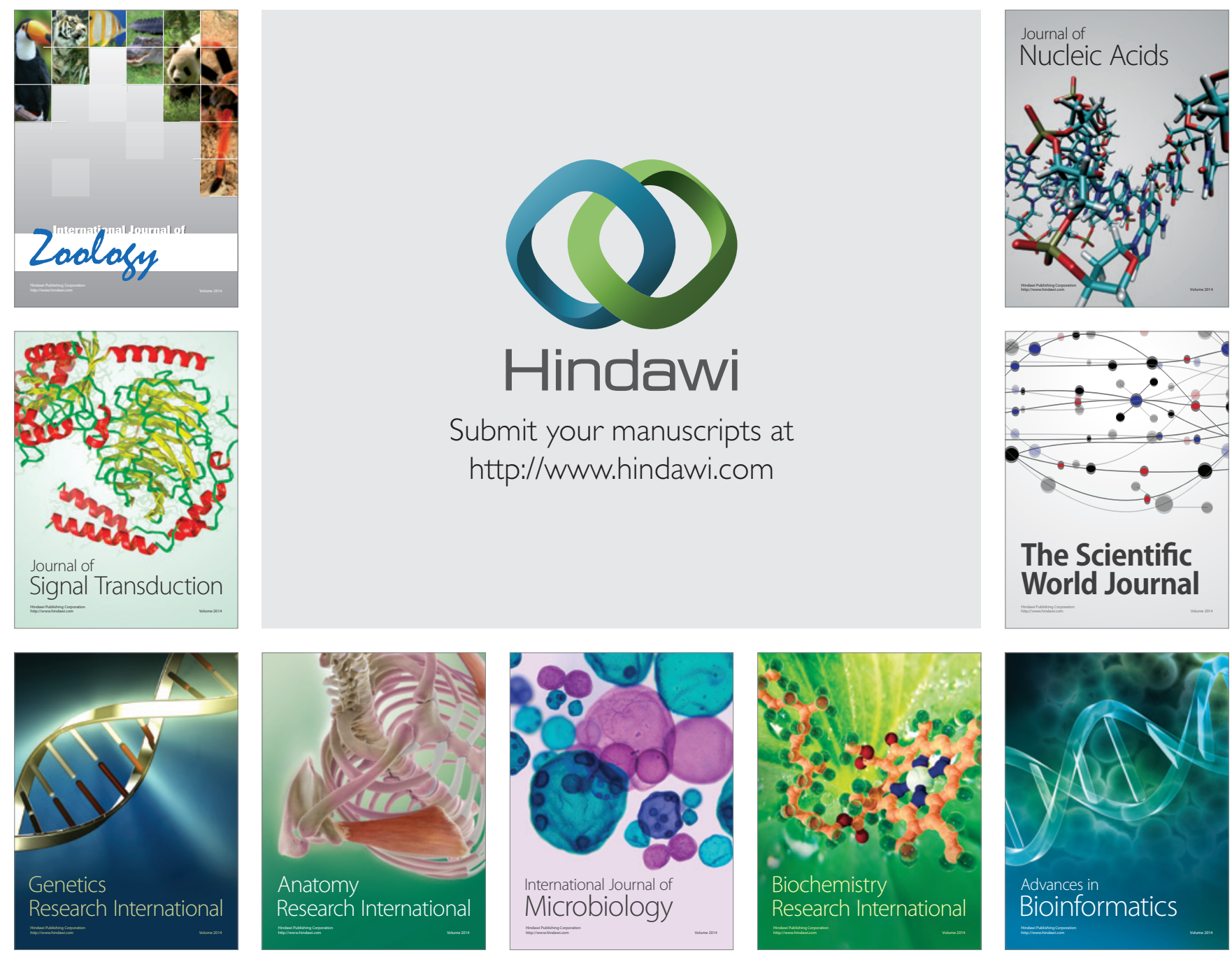

The Scientific World Journal
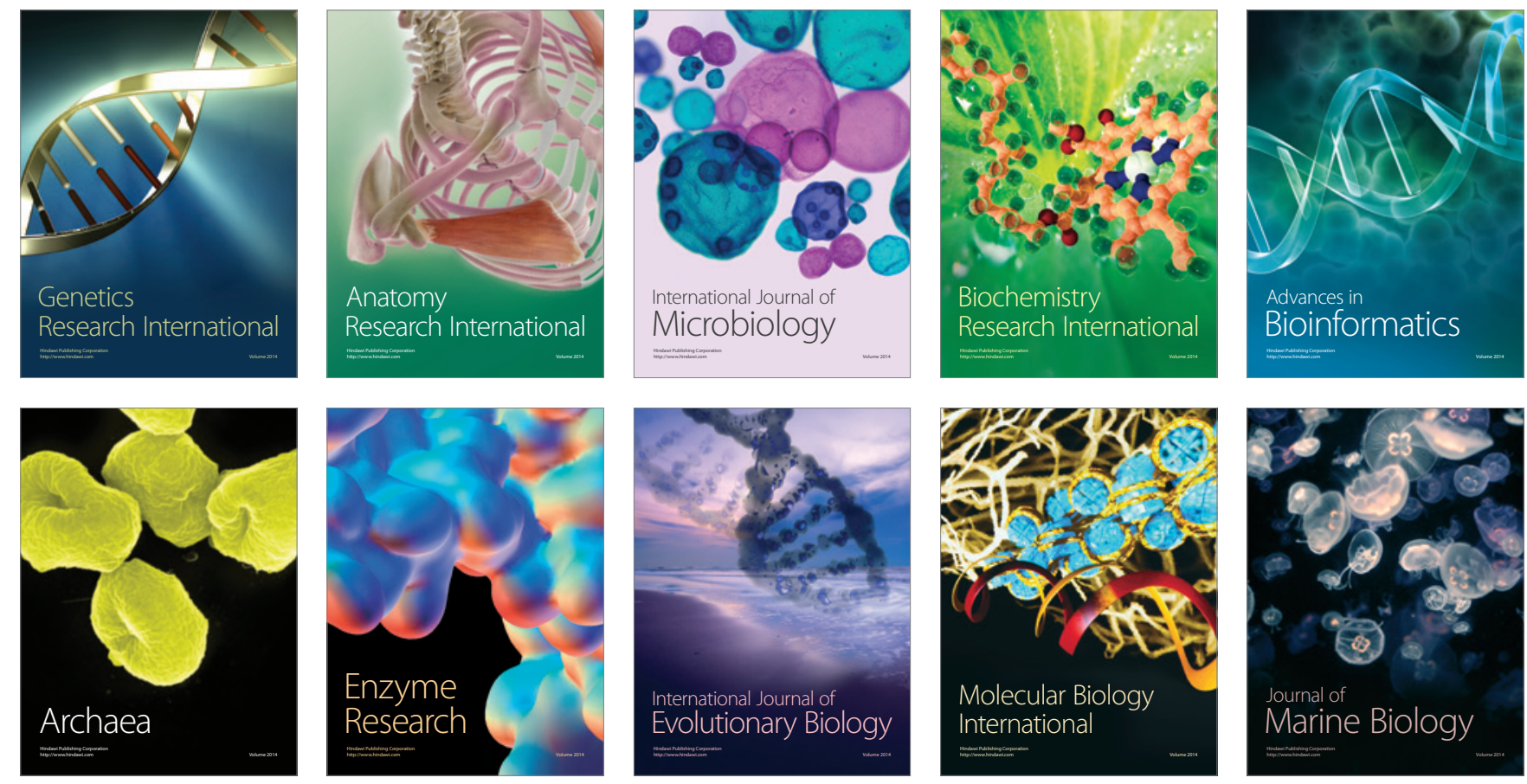